\title{
DETERMINAN FINANCIAL DISTRESS PERUSAHAAN SUBSEKTOR RITEL DI BURSA EFEK INDONESIA
}

\author{
DETERMINANT OF FINANCIAL DISTRESS ON THE RETAIL SUBSECTOR PUBLIC COMPANIES IN \\ INDONESIA STOCK EXCHANGE
}

\author{
Dony Firman Santosa*)1, Lukytawati Anggraeni**), dan Koes Pranowo ${ }^{* * *}$ \\ *) Sekolah Bisnis, IPB University \\ Jl. Raya Pajajaran, Bogor 16151 \\ ${ }^{* *}$ Departemen Ilmu Ekonomi, Fakultas Ekonomi dan Manajemen, IPB University \\ Jl. Agatis Kampus IPB Darmaga, Bogor 16680 \\ ${ }^{* * *)}$ PT Transocean Maritime \\ Jl. HR Rasuna Said, Jakarta 12940
}

\begin{abstract}
The purpose of this study were (1) To analyze financial health conditions of retail companies listed in Indonesia Stock Exchange (IDX) from 2013 to 2017, (2) To analyze the relationship between financial health conditions with companies'status based on an integral process of financial distress using Pearson correlation and (3) To analyze what factors (financial ratios and macroeconomics) which affected to financial distress using panel data regression. Fourteen retail companies were selected as samples based on purposive sampling. The results showed that retail companies in telecommunication devices, building materials, convenience store models and minimarkets had more potential to experience financial distress. The results of the Pearson correlation showed that there was a weak and negative correlation between DSCR as a proxy of financial distress with deterioration performance and cash flow problem. The financial ratio variables such as, the current ratio and return on equity, had a positive and significant effect on DSCR. Whereas, the debt to equity ratio had a negative and significant effect on DSCR. Meanwhile, significant macroeconomic variables were gross domestic product and interest rate. Gross domestic product had a positive effect on DSCR, while interest rates had a negative effect on DSCR.
\end{abstract}

Keywords: financial distress (debt service coverage ratio), financial ratios, macroeconomic, panel data regression, retail companies

\begin{abstract}
Abstrak: Tujuan dari penelitian ini adalah (1) Menganalisis kondisi kesehatan keuangan perusahaan subsektor ritel yang terdaftar di Bursa Efek Indonesia dari tahun 2013 sampai 2017, (2) Menganalisis hubungan kondisi kesehatan keuangan dengan status perusahaan berdasarkan proses integral financial distress menggunakan analisis korelasi pearson dan (3) Menganalisis faktor-faktor keuangan dan makroekonomi yang berpengaruh terhadap financial distress menggunakan analisis regresi data panel. Sebanyak 14 perusahaan ritel dipilih sebagai sampel menggunakan purposive sampling. Hasil penelitian menunjukan bahwa perusahaan ritel yang bergerak dalam bidang usaha perangkat telekomunikasi, bahan bangunan, model conveience store dan minimarket lebih berpotensi mengalami financial distress. Hasil analisis korelasi pearson menunjukan terdapat korelasi negatif yang lemah antara DSCR sebagai proxy financial distress dengan deterioration performance dan cash flow problem. Variabel rasio keuangan seperti current ratio dan return on equity berpengaruh positif dan signifikan terhadap DSCR, sedangkan debt to equity ratio memiliki pengaruh negatif dan signifkan terhadap DSCR. Sementara itu, variabel makroekonomi yang signifikan adalah gross domestic product dan interest rate. Gross domestic product berpengaruh positif terhadap DSCR sedangkan interest rate memiliki pengaruh negatif terhadap DSCR.
\end{abstract}

Kata kunci: kesulitan keuangan (DSCR), rasio keuangan, makroekonomi, regresi data panel, perusahaan ritel

\footnotetext{
${ }^{1}$ Alamat Korespondensi:

Email: donyfirmansantosa08@gmail.com
} 


\section{PENDAHULUAN}

Sektor ritel memiliki peran dan kontribusi yang besar terhadap perekonomian nasional. Selain berfungsi sebagai media dalam hubungan timbal balik antar produsen dengan konsumen, sektor ritel juga berjasa dalam penyerapan tenaga kerja dan pertumbuhan ekonomi. Berdasarkan data Badan Pusat Statistik (BPS) tahun 2016, sektor ritel memberikan sumbangsih sebesar 15,24\% terhadap total Produk Domestik Bruto (PDB) Indonesia dan mampu menyerap 22,4 juta tenaga kerja (BPS, 2016).

Bisnis ritel mencakup semua kegiatan yang melibatkan penjualan barang atau jasa secara langsung kepada konsumen akhir untuk penggunaan pribadi dan bukan untuk penggunaan bisnis. Ritel juga merupakan salah satu perangkat dari aktivitas-aktivitas bisnis yang melakukan penambahan nilai terhadap produk-produk dan layanan penjualan kepada konsumen. Lingkup ritel tidak hanya menjual produk-produk di toko baik offline ataupun online, tetapi juga melibatkan layanan jasa seperti jasa layanan antar (delivery service) dan layanan tambahan lainnya yang mampu memberikan nilai tambah terhadap barang dan jasa yang akan dikonsumsi oleh konsumen akhir (Utami, 2017).

Laporan Global Retail Development Index (GRDI) tahun 2017 yang dirilis perusahaan konsultan global A.T. Kearney (Kearney, 2017) menempatkan Indonesia di peringkat delapan negara berkembang dengan potensi ritel paling menarik. Riset GRDI memberikan peringkat terhadap 30 besar negara berkembang secara berkala setiap tahunnya dalam hal investasi ritel. Jumlah populasi Indonesia yang mencapai 260 juta jiwa, pertumbuhan kelas menengah yang terus berlanjut dan komitmen pemerintah terhadap pembangunan infrastruktur menyebabkan optimisme akan tumbuhnya bisnis ritel ke depan. Reformasi besar yang diumumkan Presiden Joko Widodo tahun 2016 dengan mengizinkan investor asing memiliki saham mayoritas di department stores dan izin kepemilikan penuh pada perusahaan e-commerce, semakin menarik minat investasi asing masuk ke Indonesia (www.atkearney.com).

Bertolak belakang dengan fakta yang terjadi di lapangan, kinerja ritel mengalami penurunan dari sisi ratarata pertumbuhan penjualan. Hasil Survei Penjualan Eceran (SPE) yang dilakukan oleh Bank Indonesia, memperlihatkan adanya tren penurunan terhadap ratarata pertumbuhan tahunan penjualan riil untuk ritel selama periode 2013-2017 (Gambar 1). Bahkan pada 2017, rata-rata pertumbuhan tahunan penjualan riil untuk ritel hanya sebesar 2,93\% (www.bi.go.id). Ratarata pertumbuhan tersebut jauh berada di bawah ratarata pertumbuhan double digit industri ritel Indonesia yang menurut AC Nilesen besarnya berada pada kisaran 10-11\%. Fenomena sepanjang tahun 2017 tentang banyaknya pemain besar ritel yang menutup gerai offline miliknya seperti Matahari Department Stores (PT Matahari Department Store Tbk), Debenhams, Lotus (PT Mitra Adiperkasa Tbk) dan Hero (PT Hero Supermarket Tbk) semakin memperkuat indikasi kesulitan finansial (financial distress) yang tengah terjadi pada industri ritel Indonesia.

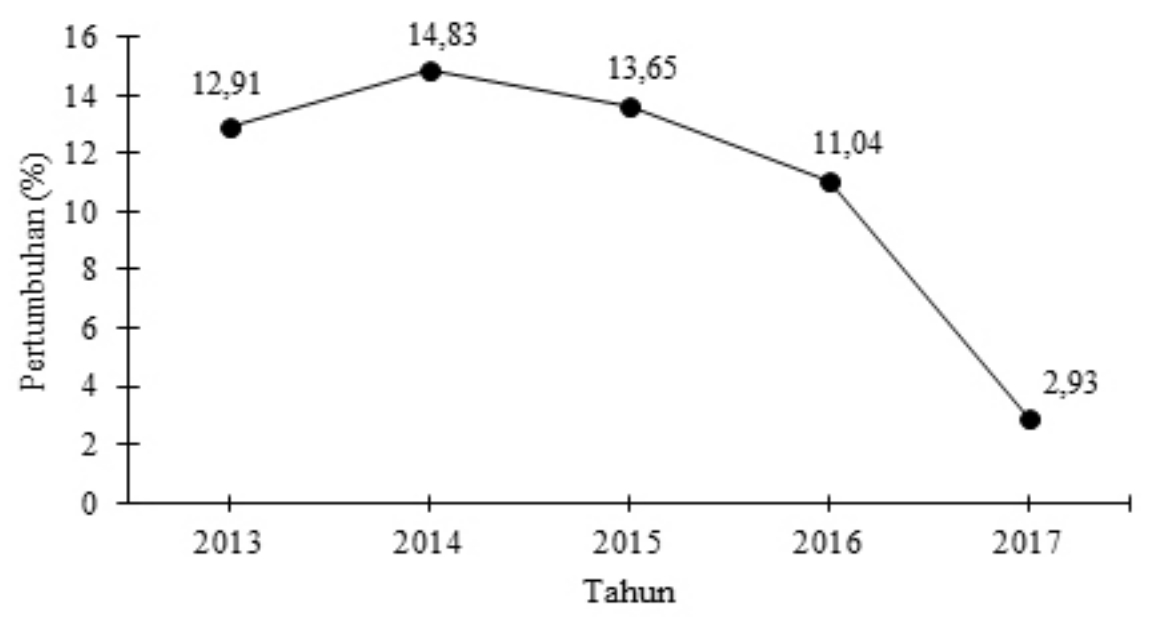

Gambar 1. Rata-rata pertumbuhan tahunan penjualan riil ritel 2013-2017 
Kinerja industri ritel nasional di pasar modal menunjukan tren berfluktuasi namun cenderung menurun. Data kumulatif aktivitas perdagangan yang diterbitkan oleh Bursa Efek Indonesia memberikan informasi ringkasan perdagangan berdasarkan industrinya, di mana subsektor ritel (perdagangan eceran) termasuk ke dalam industri perdagangan, jasa dan investasi. Volume dan value dari total saham yang diperdagangkan dari tahun 2013-2016 terus mengalami kelesuan (Tabel 1). Meskipun demikian, ditahun 2017 terjadi lonjakan akibat penambahan emiten baru sebanyak dua perusahaan. Penurunan sepanjang 20132016 menandakan semakin berkurangnya jumlah transaksi saham subsektor ritel yang diperdagangkan dalam bursa.

Indikasi kondisi financial distress dapat diketahui dari semakin meningkatnya jumlah perusahaan yang tidak dapat memenuhi kewajiban terhadap bank yang dicirikan dengan peningkatan rasio Non Performing Loan (NPL). NPL merupakan kredit dengan kualitas kurang lancar, diragukan dan macet. Berdasarkan data Statistik Perbankan Indonesia, besaran kredit dan nilai NPL perbankan terhadap sektor perdagangan ritel eceran dan besar sepanjang periode 2013-2017 terus mengalami kenaikan (Tabel 2). Rasio NPL tahun 2017 mencapai 4,46\% di mana semakin mendekati batas maksimum NPL yang diperkenankan Otoritas Jasa Keuangan (OJK) sebesar 5\%. Hal tersebut menggambarkan, semakin banyak perusahaan yang mengalami kesulitan likuiditas pada sektor tersebut.
Financial distress merupakan situasi di mana cashflow perusahaan yang tersedia tidak mampu untuk memenuhi kewajiban jangka pendek yang terdiri dari pembayaran utang jangka pendek yang jatuh tempo, utang kepada pemasok yang telah jatuh tempo serta kewajiban terhadap karyawan (Wruck, 1990). Menurut Cahyono (2013), memprediksi kondisi financial distress perusahaan penting untuk memperoleh tandatanda awal kebangkrutan sebagai bagian dari sistem peringatan dini (early warning system) bagi manajemen. Meskipun sudah banyak penelitian yang dilakukan di berbagai negara, bahasan tentang financial distress masih menjadi topik yang menarik untuk dieksplorasi dengan bermacam pendekatan. Altman (1968) menggunakan rasio keuangan untuk memprediksi financial distress. Selain rasio keuangan, Rezende et al. (2017) menambahkan variabel makroekonomi untuk memprediksi financial distress pada perusahaan publik di Brazil. Lennox (1999) meneliti penyebab kebangkrutan perusahaan publik yang berada di Inggris dan bergerak di bidang ritel sepanjang periode 1987-1994. Quarcoo dan Smedberg (2014) melakukan prediksi financial distress pada industri jasa dan ritel di Swedia dengan menggunakan 227 perusahaan sebagai sampel. Di Indonesia, penelitian terhadap variabel rasio keuangan untuk memprediksi kondisi financial distress dilakukan oleh Almilia dan Kristijadi (2003) dengan sampel perusahaan manufaktur yang terdaftar di Bursa Efek Jakarta. Nurfajrina (2016) menganalisis faktor keuangan yang berpengaruh terhadap kondisi financial distress pada perusahaan agribisnis yang terdaftar di Bursa Efek Indonesia periode 2010-2014.

Tabel 1 Ringkasan perdagangan subsektor ritel pada Bursa Efek Indonesia

\begin{tabular}{cccc}
\hline Tahun & Kapitalisasi Pasar (juta rupiah) & Volume (juta) & Value (juta rupiah) \\
\hline 2013 & 123.557 & 36.999 & 81.353 .307 \\
2014 & 142.993 & 36.712 & 76.357 .283 \\
2015 & 141.118 & 29.565 & 61.001 .572 \\
2016 & 142.862 & 25.994 & 56.629 .869 \\
2017 & 183.377 & 128.580 & 72.644 .412 \\
\hline
\end{tabular}

Tabel 2. Kredit dan NPL perbankan terhadap sektor perdagangan ritel eceran dan besar

\begin{tabular}{cccc}
\hline Tahun & Nilai NPL (milyar rupiah) & Kredit (milyar rupiah) & Rasio NPL (\%) \\
\hline 2013 & 15.415 & 578.294 & 2,67 \\
2014 & 22.782 & 716.733 & 3,18 \\
2015 & 27.948 & 792.503 & 3,53 \\
2016 & 35.789 & 841.384 & 4,25 \\
2017 & 37.677 & 845.426 & 4,46 \\
\hline
\end{tabular}


Pada penelitian ini, objek yang dipilih sebagai amatan adalah perusahaan publik subsektor ritel (perdagangan eceran) yang terdaftar di Bursa Efek Indonesia dan DSCR (debt service coverage ratio) digunakan sebagai proxy dalam memprediksi kondisi financial distress. Penelitian yang secara khusus mengkaji tentang kondisi financial distress perusahaan ritel di Indonesia masih sedikit dilakukan. Beberapa penelitian menggunakan cakupan yang lebih luas dari subsektor ritel seperti sektor perdagangan. Misalnya pada penelitian Pasaribu (2008) dan Noviandri (2014). Tujuan dari penelitan ini adalah menganalisis kondisi kesehatan terhadap keuangan perusahaan subsektor ritel yang terdaftar di BEI, menganalisis hubungan kondisi kesehatan keuangan dengan status perusahaan berdasarkan proses integral financial distress dan menganalisis faktor-faktor keuangan dan makroekonomi yang mempengaruhi kondisi financial distress pada perusahaan subsektor ritel di BEI.

\section{METODE PENELITIAN}

Data yang digunakan dalam penelitian ini adalah data sekunder berupa annual report perusahaan, publikasi Bank Indonesia dan data dari Bursa Efek Indonesia. Penelitian dilakukan selama bulan Januari hingga Agustus 2018 dengan menggunakan 14 perusahaan ritel sebagai sampel. Metode penarikan contoh yang digunakan dalam penelitian adalah penarikan contoh tak berpeluang (non-probability sampling) dengan metode purposive sampling. Pemilihan sampel ditentukan berdasarkan pertimbangan: (a) perusahaan subsektor ritel yang terdaftar di BEI dan tidak delisting pada periode 2013-2017, (b) perusahaan menerbitkan laporan keuangan yang lengkap pada periode amatan. Berikut merupakan sampel perusahaan ritel yang dipilih dalam penelitian (Tabel 3).

\section{Definisi Operasional Variabel}

Variabel Dependen

Debt Service Coverage Ratio (DSCR) ditentukan sebagai variabel dependen dalam penelitian ini di mana DSCR merupakan proxy financial distress. Perusahaan yang memiliki nilai DSCR $<1,2$ maka perusahaan berada dalam kondisi financial distress. Sebaliknya ketika nilai DSCR $\geq 1,2$ maka perusahaan dikatakan tidak mengalami financial distress (Ruster, 1996). Perhitungan DSCR adalah sebagai berikut :

\section{$\mathrm{DSCR}=(\mathrm{EAT}+[($ Depreciation + Amortization $)+$ Interest or Coupon] - Tax $) /($ Principal + Interest or Coupon)}

Keterangan: DSCR (debt service coverage ratio); EAT (earning after tax); depreciation (alokasi biaya untuk pemanfaatan aset tangible); amortization (alokasi biaya untuk pemanfaatan aset intangible); interest (beban bunga utang bank per tahun); tax (pajak korporasi per tahun); coupon (beban bunga obligasi perusahaan per tahun); principal (angsuran pembayaran secara berkala atau pembayaran obligasi korporasi).

\section{Variabel Independen}

Variabel independen di dalam penelitian ini adalah rasio keuangan dan makroekonomi. Rasio keuangan terdiri dari Current ratio, debt to equity ratio, total assets turn over, return on equity dan earning before interest, tax, depreciation and amortization to total asset. Sedangkan variabel makroekonomi terdiri dari gross domestic product (GDP) dan interest rate. Berikut merupakan variabel independen yang digunakan dalam penelitian (Tabel 4).

Tabel 3. Perusahaan subsektor ritel di BEI yang dipilih sebagai sampel penelitan

\begin{tabular}{llll}
\hline Nama Perusahaan & Kode & Nama Perusahaan & Kode \\
\hline Ace Hardware Indonesia Tbk & ACES & Matahari Department Store Tbk & LPPF \\
Sumber Alfaria Trijaya Tbk & AMRT & Mitra Adiperkasa Tbk & MAPI \\
Catur Sentosa Adiprana Tbk & CSAP & Midi Utama Indonesia Tbk & MIDI \\
Erajaya Swasembada Tbk & ERAA & Matahari Putra Prima Tbk & MPPA \\
Centratama Telekomunikasi Indonesia Tbk & CENT & Supra Boga Lestari Tbk & RANC \\
Hero Supermarket Tbk & HERO & Sona Topas Tourism Tbk & SONA \\
Kokoh Inti Arebama Tbk & KOIN & Trikomsel Oke Tbk & TRIO \\
\hline
\end{tabular}


Tabel 4. Variabel independen yang digunakan dalam penelitian

\begin{tabular}{llcl}
\hline Variabel Independen & Perhitungan & Satuan & Literatur \\
\hline Current Ratio (CR) & Current assets / Current liabilities & Rasio & (Pranowo et al. 2010) \\
Debt to Equity Ratio (DER) & Total debt / Equity & Rasio & (Noviandri, 2014) \\
Total Assets Turn Over (TATO) & Sales / Total assets & Rasio & (Nurfajrina, 2016) \\
Return on Equity (ROE) & Earning after interest and tax / Equity & Rasio & (Nurfajrina, 2016) \\
EBITDA to Total Asset (EBITDA/ & Earning before interest, tax, depreciation & Rasio & (Pranowo et al. 2010) \\
TA) & and amortization / Total assets & & \\
Gross Domestic Product (GDP) & Bank Indonesia & Ln GDP riil & (Charalambakis, 2014) \\
Interest Rate (IR) & Bank Indonesia & $\%$ & (McNamara et al. 2011) \\
\hline
\end{tabular}

\section{Hipotesis Penelitian}

Pranowo et al. (2010) mengukur corporate financial distress pada nonfinancial companies yang terdaftar pada BEI tahun 2004-2008. Hasil penelitian menunjukan bahwa Current ratio dan efficiency ratio (EBITDA to total asset) memiliki pengaruh positif dan signifikan terhadap financial distress yang diproksikan dengan DSCR. Current ratio merupakan bagian dari rasio likuiditas yang menggambarkan tingkat keamanan sebuah perusahaan. Apabila nilai Current ratio semakin besar, maka kemampuan perusahaan dalam membayar kewajiban jangka pendek atau utang yang segera jatuh tempo juga semakin besar sehingga kemungkinan terjadi kondisi financial distress akan semakin kecil dan nilai DSCR menjadi semakin besar. Ugurlu dan Aksoy (2006) menyatakan EBITDA to total Asset merupakan variabel rasio keuangan yang paling penting sebagai prediktor financial distress. Earning before interest, taxes, depreciation and amortization to total asset (EBITDA/TA) merupakan laba bersih dengan penambahan bunga, pajak, depresiasi dan amortisasi dibagi dengan total aset perusahaan. Rasio EBITDA/TA memberikan gambaran produktivitas aset perusahaan dalam menghasilkan. Semakin besar nilai EBITDA/TA maka perusahaan semakin sehat dan nilai DSCR semakin besar.

Penelitian yang dilakukan oleh Noviandri (2014) menunjukan, variabel debt to equity ratio berpengaruh positif dan signifikan terhadap financial distress pada perusahaan sektor perdagangan yang terdaftar di BEI tahun 2008-2012. Demikian halnya dengan hasil penelitian Fakoano et al. (2018) menegaskan bahwa debt to equity ratio memiliki pengaruh jangka panjang dan jangka pendek terhadap potensi financial distress pada perusahaan pengembang yang bergerak di bidang real estate di BEI. Tetapi, Nukmaningtyas (2018) mengungkapkan bahwa debt to equity ratio tidak berpengaruh secara signifikan terhadap kondisi financial distress pada perusahaan-perusahaan sektor aneka industri yang terdaftar di BEI periode 2013-2016. Debt to equity ratio mengukur sejauh mana perusahaan mengambil utang sebagai sarana untuk meningkatkan asetnya. Apabila nilai debt to equit ratio meningkat, artinya aktivitas perusahaan lebih banyak didanai dari hasil utang dibanding modal sendiri sehingga lebih berpeluang mengalami kondisi financial distress dan nilai DSCR menjadi semakin kecil.

Nurfajrina (2016) menemukan hubungan positif dan signifikan antara variabel total asset turnover dan return on equity dengan financial distress pada perusahaan agribisnis yang terdaftar di BEI tahun 2010-2014. Hal serupa juga diungkapkan melalui penelitian Widati dan Pratama (2015) terkait variabel return on equity. Return on equity mengukur laba bersih sesudah pajak dengan modal sendiri yang menunjukan efisiensi penggunaan modal sendiri. Semakin tinggi nilai return on equity, perusahaan akan semakin sehat dan nilai DSCR menjadi semakin besar. Namun, menurut Yap (2012), total asset turnover tidak memiliki pengaruh signifikan terhadap financial distress pada perusahaan publik yang terdaftar di Bursa Malaysia selama periode 1996-2005. Nilai total asset turn over menunjukan tingkat efisiensi perusahaan dalam penggunaan seluruh aset untuk menunjung aktivitas penjualan. Apabila nilai total asset turn over semakin besar, maka kemungkinan terjadinya financial distress akan semakin kecil sehingga nilai DSCR menjadi semakin besar.

Beberapa penelitian terdahulu mendapati hasil bahwa variabel makroekonomi dapat dikembangkan untuk memprediksi kondisi financial distress. Seperti penelitian yang dilakukan oleh Charalambakis (2014), menyatakan bahwa GDP memiliki hubungan negatif yang kuat terhadap kemungkinan terjadinya financial distress. GDP riil dengan proses logaritma natural (Ln) 
digunakan dalam penelitian ini. GDP menjadi indikator kesejahteraan penduduk suatu negara yang berefek pada peningkatan daya beli masyarakatnya sehingga tingkat konsumsi terhadap produk yang dihasilkan perusahaan semakin besar. Semakin tinggi GDP, semakin sehat perusahaan dan nilai DSCR menjadi semakin tinggi. Penelitian McNamara et al. (2011) menyebutkan variabel interest rate juga memiliki pengaruh positif dan signifikan dengan financial distress. Interest rate yang digunakan dalam penelitian ini adalah suku bunga pinjaman modal kerja yang diberikan oleh bank. Semakin tinggi tingkat interest rate, maka kewajiban perusahaan dalam membayar bunga juga semakin besar sehingga lebih berpotensi mengalami kondisi financial distress sehingga nilai DSCR menjadi semakin kecil. Berdasarkan uraian di atas, maka hipotesis yang diajukan dalam penelitian ini adalah sebagai berikut :

$\mathrm{H1}$ : Current ratio (CR) berpengaruh positif signifikan terhadap nilai DSCR

H1 : debt to equity ratio (DER) berpengaruh negatif signifikan terhadap nilai DSCR

H1 : total assets turn over (TATO) berpengaruh positif signifikan terhadap nilai DSCR

$\mathrm{H} 1$ : return on equity (ROE) berpengaruh positif signifikan terhadap nilai DSCR

$\mathrm{H} 1$ : EBITDA to total asset (EBITDA/TA) berpengaruh positif signifikan terhadap nilai DSCR

H1 : gross domestic product (GDP) berpengaruh positif signifikan terhadap nilai DSCR

$\mathrm{H} 1$ : interest rate (IR) berpengaruh negatif signifikan terhadap nilai DSCR
Hasil Survei Penjualan Eceran (SPE) Bank Indonesia menyatakan rata-rata pertumbuhan penjualan riil untuk ritel periode 2013-2017 mengalami tren menurun. Berdasarkan data Statistik Perbankan Indonesia, tingkat rasio NPL perbankan terhadap sektor perdagangan ritel eceran dan besar periode 2013-2017 terus mengalami peningkatan. Selain itu, data kumulatif aktivitas perdagangan yang diterbitkan oleh Bursa Efek Indonesia menunjukan nilai volume dan value total saham subsektor ritel yang diperdagangkan di bursa mulai tahun 2013-2016 terus mengalami penurunan meskipun di tahun 2017 mengalami kenaikan akibat penambahan 2 emiten baru. Beberapa fenomena tersebut mengindikasi adanya kondisi financial distress yang tengah terjadi pada perusahaan ritel yang terdaftar di BEI. Nilai DSCR digunakan sebagai indikator financial distress untuk menentukan kondisi kesehatan keuangan perusahaan, apakah perusahaan ritel termasuk kelompok perusahaan sehat (solvent) atau distress. Analisis korelasi Pearson dilakukan untuk menganalisis hubungan antara kondisi kesehatan keuangan perusahaan dengan status perusahaan berdasarkan proses integral financial distress. Kemudian, rasio keuangan dan variabel makroekomi dianalisis pengaruhnya terhadap nilai DSCR dengan metode regresi data panel. Hasil dari analisis tersebut menghadirkan arahan dan rekomendasi bagi investor beserta manajemen perusahaan ritel di BEI sebagai pertimbangan dalam proses decision-making. Kerangka pemikiran penelitian tersaji pada Gambar 2.

Penurunan rata-rata pertumbuhan penjualan, penurunan volume dan value saham yang diperdagangkan serta peningkatan NPL perusahaan ritel di BEI

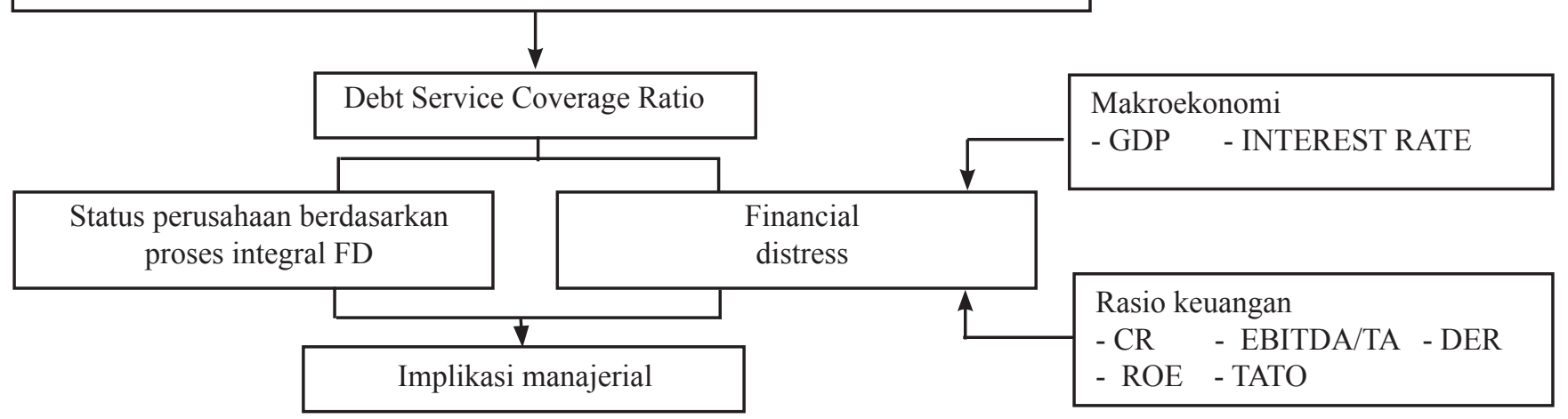

Gambar 2. Kerangka pemikiran penelitian 
Analisis kondisi kesehatan keuangan perusahaan dilakukan dengan menghitung nilai DSCR perusahaan ritel yang terdaftar di BEI. Perangkat lunak yang digunakan dalam perhitungan nilai DSCR adalah Microsoft Excel 2013. Jika nilai DSCR $<1,2$ perusahaan termasuk dalam kategori distress sedangkan jika nilai DSCR $\geq 1,2$ perusahaan termasuk dalam kategori sehat (solvent companies).

Hubungan kondisi kesehatan keuangan dengan status perusahaan berdasarkan proses integral financial distress diidentifikasi melalui analisis korelasi Pearson menggunakan software SPSS 21. Kondisi kesehatan keuangan direpresentasikan melalui nilai DSCR. Status perusahaan menurut proses integral financial distress dikategorikan menjadi good company, early impairment, deterioration performance dan cash flow problem.

Analisis regresi data panel dilakukan untuk mengidentifikasi faktor-faktor keuangan dan makroekonomi yang berpengaruh terhadap kondisi financial distress perusahaan ritel di BEI menggunakan software E-views 9. Model yang digunakan dalam penelitian ini diadaptasi dari penelitian sebelumnya yang dilakukan oleh Pranowo et al. (2010), Charalambakis (2014), Noviandri (2014) dan Nurfajrina (2016). Model persamaan pengaruh variabel rasio keuangan dan variabel makroekonomi terhadap DSCR adalah sebagai berikut :

$$
\begin{gathered}
\operatorname{DSCR}_{\mathrm{it}}=\alpha+\beta_{1} \mathrm{CR}_{\mathrm{it}}+\beta_{2} \mathrm{DER}_{\mathrm{it}}+\beta_{3} \mathrm{TATO}_{\mathrm{it}}+\beta_{4} \mathrm{ROE}_{\mathrm{it}}+ \\
\beta_{5} \mathrm{EBITDA}^{\mathrm{T} \mathrm{TA}_{\mathrm{it}}}+\beta_{6} \mathrm{GDP}_{\mathrm{it}}+\beta_{7} \mathrm{IR}_{\mathrm{it}}+\varepsilon_{\mathrm{it}} \\
\beta 1, \beta 3, \beta 4, \beta 5, \beta 6>0 \quad ; \quad \beta 2, \beta 7<0
\end{gathered}
$$

Keterangan: DSCR (debt service coverage ratio); CR (quick ratio); DER (debt to equity ratio); TATO (total assets turn over); ROE (return on equity); EBITDA/ TA (earning before interest, tax, depreciation and amortization to total assets); GDP (gross domestic product); IR (interest rate); $\varepsilon$ (komponen error).

\section{HASIL}

\section{Analisis Deskriptif}

Analisis deskriptif dilakukan terhadap variabel dependen dan independen (variabel rasio keuangan) dari 14 perusahaan subsektor ritel. Analisis deskriptif menjabarkan nilai masing-masing variabel yang dimiliki oleh perusahaan dengan mengambil nilai rataan dari tahun 2013 sampai tahun 2017 (Tabel 5). DSCR sebagai variabel dependen memiliki nilai maksimum sebesar 33,957 yang diperoleh emiten LPPF. Hal tersebut akibat kinerja perusahaan yang mampu menghasilkan laba bersih sangat besar dan tidak memiliki kewajiban pembayaran angsuran pinjaman bank sejak tahun 2015. Nilai minimum dibukukan oleh perusahaan KOIN sebesar -16,833 di mana pada tahun 2017, perusahaan mengalami kenaikan rugi bersih setelah pajak yang signifikan sebesar $228 \%$. Nilai rataan DSCR menunjukan angka 4,945 yang artinya secara umum, perusahaan subsektor ritel pada periode 2013-2017 terhindar dari kondisi financial distress.

Nilai rataan CR sebesar 1,686 belum dapat disimpulkan bahwa perusahaan ritel berada pada batas aman dalam kapasitas membayar kewajiban jangka pendeknya, karena tidak semua aset lancar dapat segera dikonversi menjadi cash ketika pembayaran piutang perusahaan terlambat atau persediaan (inventori) belum terjual optimal. Pengamatan nilai CR terbesar berasal dari perusahaan ACES yaitu 5,867. Perseroan mengalami peningkatan posisi saldo kas dan setara kas sebesar $13,27 \%$, peningkatan saldo piutang usaha sebesar $174,3 \%$ dan peningkatan saldo persediaan barang sebesar 4,453\%. Posisi utang usaha perusahaan juga mengalami penurunan $15,6 \%$ dan diikuti dengan penurunan rasio hari utang usaha yang mencerminkan kemampuan ACES dalam memenuhi kewajibannya. Nilai CR paling kecil $(0,795)$ dimiliki oleh emiten MIDI akibat strategi ekspansi yang terus dilakukan oleh perusahaan dalam hal penambahan gerai baru sehingga berdampak pada peningkatan liabilitas jangka pendek perusahaan seperti utang bank jangka pendek dan utang usaha.

Rataan DER adalah 1,826 yang menjelaskan bahwa secara umum perusahaan ritel di BEI tahun 20132017 memiliki porsi utang yang lebih besar dibanding jumlah modal sendiri. Artinya, aktivitas perusahaan lebih dominan didanai dengan utang. Nilai maksimum DER adalah 4,345 dibukukan oleh perusahaan KOIN. Perusahaan menambah kerjasama dengan pihak-pihak berelasi yang berkaitan dengan pembelian persediaan dalam bentuk utang usaha pihak berelasi sehingga semakin meningkatkan porsi total utang dengan tidak diimbangi peningkatan terhadap ekuitasnya. Nilai minimum DER adalah 0,259, diperoleh dari perusahaan ACES di mana perusahaan berhasil mencatatkan kenaikan rata-rata laba bersih setelah pajak di angka 
$10,609 \%$ setiap tahunnya sehingga berdampak pada penambahan ekuitas perusahaan dan penggunaan total utang jangka panjang tetap terkendali.

Nilai mean variabel TATO adalah 2,081 yang berarti secara umum, emiten subsektor ritel mempunyai kemampuan dalam hal efisiensi penggunaan total aset untuk menghasilkan penjualan. Nilai maksimum sebesar 4,417 berasal dari perusahaan TRIO. Perseroan mengalami penurunan aset lebih dari $90 \%$ disebabkan oleh adanya penghapusan piutang, persediaan dan uang muka pada aset lancar perusahaan. Nilai TATO minimum berasal dari perusahaan CENT sebesar 0,107 karena perusahaan kurang efektif dalam penggunaan aset miliknya.

ROE mengukur laba bersih sesudah pajak dengan modal sendiri yang menunjukan efisiensi penggunaan modal sendiri. Semakin tinggi rasio ROE, menggambarkan posisi pemilik perusahaan semakin kuat. Rataan ROE perusahaan subsektor ritel berada di angka 0,232 . Nilai ROE minimum diperoleh dari perusahaan MPPA yang besarnya-0,131.Perseroanmembukukanoperating profit negatif yang disebabkan oleh rendahnya gross profit dan peningkatan beban penjualan, umum serta administrasi. Nilai ROE maksimum diperoleh perusahaan LPPF yang besarnya 1,999. Perusahaan mampu meningkatkan laba bersih setelah pajak sebesar 30\% dan menambah saldo laba tidak dicadangkan sehingga mengakibatkan nilai ekuitas perusahaan menjadi positif dan ROE yang dihasilkan paling tinggi di antara perusahaan ritel lain. Rasio EBITDA/TA mengindikasikan produktivitas aset perusahaan untuk menghasilkan income. Rataan EBITDA/TA adalah sebesar $-0,013$. Nilai EBITDA/ TA maksimum berasal dari perusahaan LPPF yang besarnya 0,624 , sedangkan nilai minimum diperoleh dari perusahaan TRIO sebesar -2,192. Nilai EBITDA yang negatif disebabkan karena perseroan mengalami rugi bersih setelah pajak yang cukup signifikan akibat peningkatan beban umum dan administrasi seperti kerugian penurunan nilai piutang dan nilai persediaan.

\section{Kondisi Keuangan Perusahaan}

Hasil perhitungan DSCR mencerminkan kondisi kesehatan terhadap keuangan perusahaan. Perusahaan dengan kondisi keuangan yang sehat mempunyai nilai $\mathrm{DSCR} \geq 1,2$ sedangkan jika nilai $\mathrm{DSCR}<1,2$ maka kondisi keuangan perusahaan termasuk dalamkelompok distress. Secara keseluruhan, perusahaan subsektor ritel yang termasuk dalam kelompok perusahaan sehat (solvent companies) selama periode 2013-2017 adalah ACES, CENT, HERO, LPPF, MPPA, RANC dan SONA (50\%). Sedangkan, perusahaan yang termasuk dalam distress companies adalah AMRT, CSAP, ERAA, KOIN, MAPI, MIDI dan TRIO (50\%). Laba bersih setelah pajak yang bernilai negatif, besarnya utang bank jangka pendek dan kewajiban jangka panjang yang jatuh tempo dalam waktu satu tahun menjadi penyebab perusahaan mengalami financial distress.

Tabel 5. Analisis deskiptif nilai rataan variabel dependen dan variabel rasio keuangan perusahaan subsektor ritel di BEI tahun 2013-2017

\begin{tabular}{lcccccc}
\hline Emiten & DSCR & CR & DER & TATO & ROE & EBITDA/TA \\
\hline ACES & 11,708 & 5,867 & 0,259 & 1,454 & 0,23 & 0,273 \\
AMRT & 0,772 & 0,923 & 2,972 & 3,003 & 0,124 & 0,171 \\
CSAP & 0,238 & 1,142 & 2,774 & 1,964 & 0,085 & 0,069 \\
ERAA & 0,323 & 1,414 & 1,171 & 2,594 & 0,088 & 0,099 \\
CENT & 5,356 & 1,862 & 0,293 & 0,107 & $-0,046$ & 0,044 \\
HERO & 18,829 & 1,341 & 0,46 & 1,691 & 0,021 & 0,069 \\
KOIN & $-16,833$ & 1,203 & 4,345 & 2,379 & 0,129 & 0,048 \\
LPPF & 33,957 & 0,992 & 3,78 & 2,165 & 1,999 & 0,624 \\
MAPI & 0,523 & 1,453 & 2,173 & 1,342 & 0,064 & 0,136 \\
MIDI & 0,65 & 0,795 & 3,563 & 2,181 & 0,178 & 0,19 \\
MPPA & 9,868 & 1,215 & 1,741 & 2,152 & $-0,131$ & 0,051 \\
RANC & 3,659 & 1,487 & 0,802 & 2,435 & 0,046 & 0,107 \\
SONA & 1,877 & 2,978 & 0,702 & 1,244 & 0,073 & 0,135 \\
TRIO & $-1,7$ & 0,932 & 0,523 & 4,417 & 0,379 & $-2,192$ \\
\hline Rataan & 4,945 & 1,686 & 1,826 & 2,081 & 0.232 & $-0,013$ \\
\hline
\end{tabular}


Pengamatan yang dilakukan terhadap distress companies memperlihatkan, jenis ritel modern seperti convenience store dan minimarket (AMRT dan MIDI) lebih rentan mengalami kondisi financial distress akibat strategi ekspansi dalam rangka pertumbuhan bisnis perseoran sehinggaberdampak padapeningkatanjumlah utang bank. Selain itu, berdasarkan bidang usaha yang digeluti, perusahaan ritel perangkat telekomunikasi (ERAA dan TRIO) lebih sering berada pada kondisi financial distress akibat besarnya jumlah pinjaman kepada pihak ketiga untuk memenuhi kebutuhan modal kerja. Demikian juga perusahaan ritel yang bergerak dalam bidang usaha bahan bangunan (CSAP dan KOIN) berpotensi mengalami financial distress. Hal tersebut disebabkan masih melambatnya pertumbuhan properti sejak tahun 2013 dan berdampak terhadap permintaan bahan bangunan secara umum.

\section{Hubungan Kondisi Keuangan dengan Status Perusahaan Ritel Berdasarkan Proses Integral Financial Distress}

Proses integral financial distress bertujuan untuk mengelompokan status perusahaan ritel ke dalam empat kategori, yaitu good company, early impairment, deterioration performance dan cash flow problem. Perusahaan yang mengalami penurunan pendapatan (revenue) lebih dari 20\% dikategorikan sebagai early impairment dan perusahaan yang mengalami penurunan laba (profit) lebih dari 20\% dikelompokan sebagai deterioration performance. Adapun perusahaan yang memiliki cashflow operasional defisit termasuk ke dalam kategori cashflow problem, sedangkan perusahaan yang tidak termasuk dalam ketiga kategori tersebut digolongkan ke dalam kelompok good company.

Hasil pada Tabel 6 mengindikasikan bahwa perusahaan subsektor ritel yang benar-benar sehat secara finansial sebesar 51,429\%. Tahun 2015 dan 2017, jumlah perusahaan dengan kondisi keuangan good company mencapai titik paling rendah yaitu 6 perusahaan $(42,857 \%)$ dari total 14 perusahaan ritel. Pada tahun 2015, tantangan yang dihadapi adalah perlambatan perekonomian nasional dan depresiasi rupiah terhadap dolarAmerika Serikat sedangkan tahun 2017, Konsumsi rumah tangga masih tumbuh terbatas, khususnya pada belanja makanan dan pakaian disertai pergeseran pola konsumsi ke leisure. Di samping itu, terjadi preferensi menunda konsumsi untuk masyarakat menengah atas dan lebih memilih untuk menyimpan uangnya di bank. Hal tersebut terlihat dari Dana Pihak Ketiga (DPK) yang tumbuh di atas kredit bank pada akhir tahun 2017.

Hubungan kondisi kesehatan keuangan dengan status perusahaan ritel berdasarkan proses integral financial distress dianalisis menggunakan analisis korelasi Pearson. Berdasarkan hasil pada Tabel 7, terdapat korelasi negatif yang signifikan antara DSCR dengan status deterioration performance dan cashflow problem meskipun dengan tingkat keeratan hubungan yang lemah. Artinya, semakin perusahaan mengalami deterioration performance atau cashflow problem maka dapat dipastikan nilai DSCR perusahaan akan semakin rendah sehingga lebih memungkinkan mengalami kondisi financial distress.

\section{Pengaruh Variabel Rasio Keuangan dan Makroekonomi terhadap Financial Distress}

Pemilihan model terbaik antara Pooled Ordinary Least Square (PLS) dengan Fixed Effect Model (FEM) ditentukan dengan menggunakan uji Chow di mana hasil pengujian menunjukan besar p-value adalah 0,001 dan kurang dari taraf nyata 0,05 sehingga FEM merupakan model yang terpilih. Kemudian, pemilihan model terbaik antara Fixed Effect Model (FEM) dengan Random Effect Model (REM) menggunakan uji Hausman dan hasilnya menampilkan Hausman statistic set to zero. Artinya tidak terdapat pengaruh acak sehingga dinyatakan uji Hausman tidak valid. Oleh sebab itu, alternatif pemilihan model terbaik dipertimbangkan berdasarkan R-square adjusted yang paling tinggi sehingga dari ketiga model tersebut dipilih FEM sebagai model terbaik.

Uji normalitas menggunakan Jarque-Bera test diperoleh nilai probabilitasnya sebesar 0,000 di mana nilai tersebut kurang dari taraf nyata 0,05 sehingga disimpulkan sisaan tidak menyebar normal. Permasalahan sisaan tidak menyebar normal dapat diatasi dengan pembobotan pada model. Selanjutnya, Asumsi kenormalan pada model yang terboboti diuji kembali dengan menggunakan Jarque-Bera test. Hasil pengujian diperoleh nilai probabilitas sebesar 0,199 lebih besar dari taraf nyata 0,05 sehingga disimpulkan sisaan menyebar normal dan model setelah pembobotan lolos asumsi normalitas. 
Tabel 6. Proses integral financial distress perusahaan subsektor ritel $2013-2017$

\begin{tabular}{ccccc}
\hline Tahun & Good Company & Early Impairment & Deterioration Performance & Cashflow Problem \\
\hline 2013 & $8(57,143 \%)$ & $0(0 \%)$ & $1(7,143 \%)$ & $5(35,714 \%)$ \\
2014 & $7(50 \%)$ & $0(0 \%)$ & $4(28,571 \%)$ & $3(21,426 \%)$ \\
2015 & $6(42,857 \%)$ & $1(7,143 \%)$ & $5(35,714 \%)$ & $2(14,286 \%)$ \\
2016 & $9(64,286 \%)$ & $1(7,143 \%)$ & $2(14,286 \%)$ & $2(14,286 \%)$ \\
2017 & $6(42,857 \%)$ & $0(0 \%)$ & $3(21,426 \%)$ & $5(35,714 \%)$ \\
\hline
\end{tabular}

Tabel 7. Hasil analisis korelasi pearson kondisi kesehatan keuangan dengan status perusahaan ritel berdasarkan proses integral financial distress.

\begin{tabular}{|c|c|c|c|c|c|}
\hline \multicolumn{6}{|c|}{ Correlations } \\
\hline & & DSCR & EAR_IMP & DET_PER & CF_PROB \\
\hline DSCR & $\begin{array}{l}\text { Pearson Correlation } \\
\text { Sig. (2-tailed) } \\
\mathrm{N}\end{array}$ & $\begin{array}{c}1 \\
70\end{array}$ & $\begin{array}{c}-.026 \\
.832 \\
70\end{array}$ & $\begin{array}{c}-.237^{*} \\
.049 \\
70\end{array}$ & $\begin{array}{c}-.288^{*} \\
.015 \\
70\end{array}$ \\
\hline EAR_IMP & $\begin{array}{l}\text { Pearson Correlation } \\
\text { Sig. }(2 \text {-tailed }) \\
\mathrm{N}\end{array}$ & $\begin{array}{l}-.026 \\
.832 \\
70\end{array}$ & $\begin{array}{l}1 \\
70\end{array}$ & $\begin{array}{l}.102 \\
.402 \\
70\end{array}$ & $\begin{array}{l}.637 * * \\
.000 \\
70\end{array}$ \\
\hline DET_PER & $\begin{array}{l}\text { Pearson Correlation } \\
\text { Sig. (2-tailed }) \\
\mathrm{N}\end{array}$ & $\begin{array}{c}-.237^{*} \\
.049 \\
70\end{array}$ & $\begin{array}{l}.102 \\
.402 \\
70\end{array}$ & $\begin{array}{l}1 \\
70\end{array}$ & $\begin{array}{l}.362^{* *} \\
.002 \\
70\end{array}$ \\
\hline CF_PROB & $\begin{array}{l}\text { Pearson Correlation } \\
\text { Sig. (2-tailed) }\end{array}$ & $\begin{array}{c}-.288^{*} \\
.015 \\
70\end{array}$ & $\begin{array}{l}.637 * * \\
.000 \\
70\end{array}$ & $\begin{array}{l}.362 * * \\
.002 \\
70\end{array}$ & 1 \\
\hline
\end{tabular}

*) Correlation is significant at the 0.005 level (2-tailed).

**) Correlation is significant at the 0.001 level (2-tailed).

Multikolinearitas terjadi ketika terdapat hubungan linier sempurna antar variabel independen di dalam model regresi. Pendeteksian multikolinearitas dapat dilakukan dengan menggunakan matriks korelasi. Menurut Ghozali dan Ratmono (2013), jika matriks korelasi bernilai kurang dari 0,9 maka tidak terjadi terjadi multikolinearitas dalammodel. Hasilujimultikolineritas terhadap model yang terboboti memperlihatkan data lolos pengujian multikolinearitas.

Permasalahan heteroskedastisitas terjadi ketika sisaan pada model regresi memiliki keragaman yang tidak konstan. Uji statistik yang digunakan untuk mendeteksi adanya pelanggaran heteroskedastisitas pada penelitian ini adalah uji White. Hasil dari White heteroscedaticity test menunjukan nilai Obs*R-squared memiliki nilai probabilitas 0,07 lebih besar dari alpha 0,05 sehingga mengindikasikan ragam sisaan homogen atau model setelah pembobotan terbebas dari pelanggaran asumsi heteroskedastisitas.

Permasalahan autokorelasi terjadi ketika terdapat hubungan antara sisaan satu pengamatan dengan sisaan pengamatanlainnya. Pendeteksian masalahautokorelasi menggunakan uji Breusch-Godfrey di mana hasilnya menyatakan bahwa nilai Obs*R-squared memiliki nilai probabilitas 0,145 lebih besar dari taraf nyata 0,05 . Hal tersebut mengindikasikan sisaan bersifat acak dan saling bebas serta model setelah pembobotan terbebas dari pelanggaran autkorelasi.

Model pengaruh tetap atau FEM dengan pembobotan terpilih sebagai model terbaik setelah melalui serangkaian uji pemilihan model serta terbebas dari pelanggaran asumsi normalitas, multikolinearitas, hetersokedastisitas dan autokorelasi. Nilai R-squared yang diperoleh sebesar 84,6\%, artinya keragaman financial distress dengan proxy DSCR dapat dijelaskan oleh variabel independen berupa variabel rasio keuangan dan makroekeonomi sebesar 84,6\%, sedangkan 15,4\% sisanya dijelaskan oleh variabel lain di luar model. Secara keseluruhan, F-statistik 13,449 dengan nilai probabilitas 0,000 mengindikasikan bahwa minimal ada satu variabel independen yang memiliki hubungan linear dengan DSCR pada taraf nyata 5\% (Tabel 8). 
Tabel 8. Determinan financial distress perusahaan ritel yang terdaftar di BEI

\begin{tabular}{lcccc}
\hline Variabel independen & Koefisien & Std. Error & t-Statistic & Probabilitas \\
\hline C & $-210,137$ & 40,268 & $-5,218$ & 0,000 \\
CR & 1,585 & 0,384 & 4,129 & $0,000^{*}$ \\
DER & $-2,077$ & 0,963 & $-2,158$ & $0,036^{*}$ \\
TATO & $-0,529$ & 0,922 & $-0,573$ & 0,569 \\
ROE & 4,369 & 1,644 & 2,657 & $0,011^{*}$ \\
EBITDA/TA & 0,653 & 0,473 & 1,382 & 0,173 \\
GDP & 14,027 & 2,689 & 5,216 & $0,000^{*}$ \\
IR & $-0,693$ & 0,264 & $-2,628$ & $0,011^{*}$ \\
\hline R-squared & 0,846 & F-statistik & 13,449 \\
Adjusted R-squared & 0,783 & Prob. (F-stat.) & 0,000 \\
\hline *) Correlation is significant at the 0,005 level (2-tailed). & & \\
**) Correlation is significant at the 0,001 level (2-tailed). & &
\end{tabular}

Hasil analisis regresi data panel menunjukan variabel rasio keuangan seperti Current ratio dan return on equity berpengaruh positif dan signifikan terhadap DSCR, sedangkan variabel rasio keuangan yang lain seperti debt to equity ratio memiliki pengaruh negatif dan signifkan terhadap DSCR. Sementara itu, variabel makroekonomi yang signifikan adalah GDP dan interest rate. GDP berpengaruh positif terhadap DSCR sedangkan interest rate memiliki pengaruh negatif terhadap DSCR.

Rasio likuiditas diwakili oleh CR di mana peningkatan satu satuan variabel CR akan berpengaruh terhadap penambahan nilai DSCR sebesar 1,585. Berdasarkan besaran nilai koefisien, variabel $\mathrm{CR}$ memberikan kontribusi paling kecil terhadap nilai DSCR dibandingkan variabel keuangan lainnya. Kemungkinan penyebabnya adalah tidak semua Current asset bisa segera dikonversi dalam bentuk cash akibat masih dalam bentuk persediaan (inventori) dan piutang yang terlambat bayar. Variabel CR berpengaruh positif dan signifikan terhadap nilai DSCR selaku proxy financial distress dan sesuai dengan hipotesis awal penelitian (H1). Hal ini sejalan dengan penelitian yang dilakukan oleh Pranowo et al. (2010), Purnomo (2013) dan Ufo (2015).

Variabel DER berpengaruh negatif dan signifikan terhadap nilai DSCR dengan koefisien -2,077. Artinya, jika nilai DER meningkat satu satuan maka nilai DSCR akan berkurang sebesar 2,077 dengan asumsi variabel lain dianggap konstan. Semakin besar nilai DER menunjukan aktivitas perusahaan lebih banyak didanai hasil utang daripada modal sendiri. Perusahaan dengan rasio DER tinggi lebih berpotensi mengalami kondisi financial distress karena peningkatan kewajiban dalam pembayaran angsuran pokok pinjaman, beban bunga bank atau obligasi. Hal ini sesuai dengan penelitian yang dilakukan oleh Noviandri (2014) bahwa debt to equity ratio memiliki pengaruh signifikan terhadap financial distress dan sejalan dengan hipotesis awal penelitian (H2).

ROE memiliki pengaruh positif dan signifikan terhadap nilai DSCR dengan koefisien 4,369. Hal tersebut dapat dimaknai peningkatan satu rasio ROE akan berkontribusi terhadap peningkatan nilai DSCR sebesar 4,369 cateris paribus. Nilai ROE yang tinggi dapat menghasilkannilaipengembalianatasinvestasi terhadap ekuitas semakin tinggi sehingga menguntungkan pemilik modal. Hal ini sejalan dengan penelitian Haq et al. (2013) yang menyatakan jika ROE meningkat maka kemungkinan perusahaan akan mengalami financial distress akan menurun. Penelitan Widati dan Pratama (2015) serta Nurfajrina (2016) turut mengungkapkan bahwa return on equity (ROE) berpengaruh signifikan terhadap financial distress, di samping itu juga sesuai dengan hipotesis awal penelitian (H4).

Variabel GDP merepresentasikan tingkat kemakmuran penduduk dalam suatu negara. Semakin besar GDP suatu negara merupakan cerminan kinerja ekonomi yang membaik di negara tersebut. Hasil analisis regresi data panel menunjukan GDP berpengaruh positif dan sangat signifikan terhadap nilai DSCR dengan koefisien terbesar di antara variabel independen lain yaitu 14,027. Hal tersebut menandakan peningkatan GDP sebesar satu satuan berdampak pada peningkatan nilai DSCR sebesar 14,027 dengan asumsi variabel lain dianggap konstan. Hal tersebut sesuai dengan penelitian Charalambakis (2014) yang menyimpulkan bahwa GDP memiliki pengaruh negatif terhadap 
kemungkinan terjadinya financial distress dan sejalan dengan hipotesis awal penelitian (H6). GDP menjadi indikator kesejahteraan masyarakat yang berefek pada peningkatan daya beli sehingga tingkat konsumsi terhadap produk yang dihasilkan perusahaan semakin besar. Bagi perusahaan, kondisi demikian sangat menguntungkan sebab likuiditas perusahaan semakin baik dan berpotensi terhindar dari kondisi financial distress.

Variabel IR memiliki pengaruh negatif dan signifikan terhadap nilai DSCR dengan koefisien sebesar -0,693. Hal tersebut dapat dimaknai peningkatan $1 \%$ variabel IR akan berkontribusi terhadap penurunan nilai DSCR sebesar 0,693 cateris paribus. Semakin tinggi tingkat interest rate maka kewajiban perusahaan dalam membayar bunga juga semakin besar sehingga lebih berpotensi mengalami kondisi financial distress. Hasil dari penelitian ini sesuai dengan penelitian yang dilakukan McNamara et al. (2011) dan sejalan dengan hipotesis awal penelitian $(\mathrm{H} 7)$.

\section{Implikasi Manajerial}

Manajemen perusahaan harus secara konsisten menjaga stabilitas variabel rasio keuangan yang berpengaruh signifikan terhadap kemungkinan terjadinya financial distress seperti: Current ratio, return on equity dan debt to equity ratio. Selain itu, ketika status perusahaan sudah mencapai tahap deterioration performance atau bahkan cashflow problem, manajemen harus waspada karena nilai debt service coverage ratio akan semakin rendah. Hal tersebut menyebabkan perusahaan lebih berpotensi mengalami kondisi financial distress.

Investor menggunakan analisis teknikal untuk mengamati pergerakan harga saham. Di samping itu, penerapan analisis fundamental juga dibutuhkan untuk mengkaji kondisi perusahaan secara lebih mendalam. Hasil penelitian mengungkapkan, beberapa variabel rasio keuangan dan variabel makroekonomi memiliki pengaruh nyata terhadap financial distress sehingga dapat dijadikan pertimbangan bagi investor dalam pengambilan keputusan berinvestasi pada perusahaan subsektor ritel di pasar modal.

Pemerintah berperan penting dalam peningkatan pertumbuhan ekonomi nasional. Salah satu indikator penting untuk mengetahui pertumbuhan ekonomi di suatu negara dalam suatu periode tertentu adalah
GDP. Pemerintah selaku regulator diharapkan mampu merumuskan kebijakan yang mendorong investasi masuk ke dalam negeri melalui penciptaan iklim bisnis yang kondusif.

\section{KESIMPULAN DAN SARAN}

\section{Kesimpulan}

Berdasarkan perhitungan DSCR, perusahaan ritel di BEI yang mengalami kondisi financial distress adalah AMRT, CSAP, ERAA, KOIN, MAPI, MIDI dan TRIO. Sedangkan yang termasuk dalam kelompok perusahaan sehat (solvent companies) adalah ACES, CENT, HERO, LPPF, MPPA, RANC dan SONA. Pengamatan terhadap distress companies menunjukan perusahaan ritel modern dengan model convenience store, minimarket, perusahaan ritel perangkat telekomunikasi dan perusahaan ritel yang bergerak dalam bidang usaha bahan bangunan lebih berpotensi mengalami financial distress.

Hasil analisis korelasi Pearson menunjukan, terdapat korelasi negatif yang signifikan antara DSCR dengan status deterioration performance dan cashflow problem meskipun dengan tingkat keeratan hubungan yang lemah. Artinya, semakin perusahaan mengalami deterioration performance atau cashflow problem maka dapat dipastikan nilai DSCR perusahaan akan semakin rendah. Akibatnya, perusahaan cenderung lebih mungkin berada pada kondisi financial distress.

Model yang paling sesuai menggambarkan kondisi financial distress (proxy DSCR) perusahaan ritel yang terdaftar di BEI periode 2013-2017 adalah FEM dengan pembobotan cross-section weights. Hasil analisis regresi data panel tentang faktor-faktor variabel rasio keuangan dan makroekonomi yang berpengaruh terhadap financial distress menunjukan, variabel rasio keuangan seperti current ratio dan return on equity berpengaruh positif dan signifikan terhadap DSCR, sedangkan variabel rasio keuangan yang lain seperti debt to equity ratio memiliki pengaruh negatif dan signifikan terhadap DSCR. Sementara itu, variabel makroekonomi yang signifikan adalah GDP dan interest rate. GDP berpengaruh positif terhadap DSCR sedangkan interest rate memiliki pengaruh negatif terhadap DSCR. 


\section{Saran}

Penelitian lebih lanjut perlu dikembangkan dengan mengkaji variabel-variabel lain yang diduga mempunyai pengaruh terhadap financial distress perusahaan seperti: corporate governance, ukuran perusahaan, informasi pasar modal dan variabel rasio keuangan yang belum digunakan dalam penelitian. Selain itu, perlu dipertimbangkan aspek business life cycle terhadap kemungkinan terjadinya financial distress. Beberapa tahapan business life cycle perusahaan diantaranya: start up, growth, maturity atau decline.

\section{DAFTAR PUSTAKA}

[BI] Bank Indonesia. 2018. Survei penjualan eceran http://www.bi.go.id/id/publikasi/survei/ penjualan-eceran/Default.aspx $\quad[30 \quad$ Januari 2018].

[BPS] Badan Pusat Statistik. 2016. Laju pertumbuhan y on y produk domestik bruto menurut lapangan usaha(persen)2014-2016.https://www.bps.go.id/ dynamictable/2016/08/05/1216/-seri-2010-lajupertumbuhan-y-on-y-produk-domestik-brutomenurut-lapangan-usaha-persen-2014-2016. html. [17 Januari 2018].

Almilia LS, Kristijadi. 2003. Analisis rasio keuangan untuk memprediksi kondisi financial distress perusahaan manufaktur yang terdaftar di Bursa Efek Jakarta. Jurnal Akuntansi dan Auditing Indonesia 7(2): 183-210.

Altman EI. 1968. Financial ratios, discriminant analysis and the prediction of corporate bankruptcy. Journal of Finance 22(4): 589-609. https://doi. org/10.1111/j.1540-6261.1968.tb00843.x.

Cahyono DH. 2013. Prediksi financial distress perusahaan BUMN di Indonesia [tesis]. Yogyakarta: Universitas Gadjah Mada.

Charalambakis EC. 2014. On corporate financial distress prediction: What can we learn from private firms in a small open economy?. Working Paper 1: 3-31.

Fakoano V, Achsani NA, Maulana TNA. 2018. Kinerja keuangan perusahaan properti menggunakan metode Zmijewski. Jurnal Aplikasi Manajemen dan Bisnis 4(3): 341-353. https://doi. org/10.17358/jabm.4.3.341.

Ghozali I, Ratmono D. 2013. Analisis Multivariat dan Ekonometrika: Teori, Konsep dan Aplikasi dengan Eviews 8. Semarang: Badan Penerbit
Universitas Diponegoro.

Haq S, Arfan M, Siswar D. 2013. Analisis rasio keuangan dalam memprediksi financial distress (studi pada perusahaan yang terdaftar di BEI). Jurnal Akuntansi Pascasarjana Universitas Syiah Kuala 2(1):37-46.

Kearney AT. 2017. Global retail development index.https://www.atkearney.com/ documents/10192/12766530/The+Age+of +Fo cus $\%$ E2\%80\%93 The $+2017+$ Global + Retail + D evelopment+Index.pdf/770c5a53-d656-4b14bc6c-b0db5e48fdc1. [23 Januari 2018].

Lennox C. 1999. Identifying failing companies: A reevaluation of the logit, probit and DA approaches. Journal of Economics and Business 51(1): 347-364. https://doi.org/10.1016/S01486195(99)00009-0.

McNamara R, Duncan K, Kelly S. 2011. Micro and macro determinants of financial distress. Prosiding International Business Research Conference ke-15; Melbourne, 21 - 23 Nov 2011. Melbourne: World Business Institute Australia. hlm 1-25.

Noviandri T. 2014. Peranan analisis rasio keuangan dalam memprediksi kondisi financial distress perusahaan subsektor perdagangan. Jurnal Ilmu Manajemen 2(4): 1655-1665.

Nukmaningtyas F. 2018. Penggunaan rasio profitabilitas, likuiditas, leverage dan arus kas untuk memprediksi financial distress (studi pada perusahaan sektor aneka industri yang terdaftar di bursa efek indonesia periode 2013-2016). Jurnal Administrasi Bisnis 61(2): 136-143. https://doi.org/10.25139/jai.v2i1.1149.

Nurfajrina A. 2016. Analisis financial distress dan dampak terhadap kinerja saham pada perusahaan agribisnis di Bursa Efek Indonesia. Jurnal Keuangan dan Perbankan 20(3): 448-457. https://doi.org/10.26905/jkdp.v20i3.280.

Pasaribu RBF. 2008. Penggunaan binary logit untuk prediksi financial distress perusahaan yang tercatat di Bursa Efek Jakarta (Studi kasus emiten industri perdagangan). Jurnal Ekonomi Bisnis \& Akuntansi Ventura 11(2): 153-172.

Pranowo K, Achsani NA, Manurung AH, Nuryartono N. 2010. Determinant of corporate financial distress in an emerging market economy:empirical evidence from the Indonesian Stock Exchange 2004-2008. International Research Journal of Finance and Economics 52(1): 81-90.

Purnomo S. 2013. Analisis rasio keuangan sebagai alat 
prediksi financial distress perusahaan. Jurnal Ekonomi dan Bisnis 27(1): 84-90.

Quarcoo NL, Smedberg C.2014. The road to bankruptcy: a study on predicting financial distress in Sweden [tesis]. Umea: Umea University.

Rezende FF, Montezano RM, Oliviera FN, Lameira VJ. 2017. Predicting financial distress in publicly-traded companies. Revista Contabilidade\&Financas 28(1): 390-406. https://doi.org/10.1590/1808-057x201704460.

Ruster J. 1996. Mitigating commercial risks in project finance. Public Policy for Private Sector. New York: The World Bank.

Ufo A. 2015. Determinants of financial distress in manufacturing firms of Ethiopia. Research Journal of Finance and Accounting 6(17): 9-17.

Ugurlu M, Aksoy H. 2006. Prediction of corporate financial distress in an emerging market: the case of Turkey. Cross Cultural Management: An International Journal 13(4): 277-295. https:// doi.org/10.1108/13527600610713396.

Utami CW. 2017. Manajemen Ritel: Strategi dan Implementasi Operasional Bisnis Ritel Modern Indonesia. Ed ke-3. Jakarta: Penerbit Salemba Empat.

Widati WL, Pratama BA. 2015. Pengaruh Current ratio, debt to equity ratio, dan return on equity, untuk memprediksi kondisi financial distress. Journal of Accounting and Banking 4(1): 1-13.

Wruck K. 1990. Financial distress, reorganization and organizational efficiency. Journal of Financial Economics 27: 2419-446. https://doi. org/10.1016/0304-405X(90)90063-6.

Yap BCF. 2012. Evaluating company failure in Malaysia using financial ratios and logistic regression. Asian Journal of Finance and Accounting 4(1): 330-344. https://doi.org/10.5296/ajfa. v4i1.1752. 